\title{
Segmenting Consumers’ Reasons For and Against Ethical Consumption
}

Citation:

Burke, P.F., Eckert, C., \& Davis, S. (2014). Segmenting consumers' reasons for and against ethical consumption. European Journal of Marketing, 48(11/12), 2237-2261.

DOI: http://dx.doi.org/10.1108/EJM-06-2013-0294

Author Affiliations:

University of Technology Sydney (UTS), Australia

Corresponding author:

Dr Paul F. Burke via email Paul.burke@uts.edu.au 


\section{Segmenting Consumers’ Reasons For and Against Ethical Consumption}

Purpose: This paper quantifies the relative importance of reasons used to explain consumers' selection and rejection of ethical products, accounting for differences in ethical orientations across consumers.

Approach: Reviewing previous literature and drawing on in-depth interviews, a taxonomy of reasons for and against ethical purchasing is developed. An online survey incorporating best-worst scaling determines which reasons feature more in shaping ethical consumerism. Cluster analysis and multinomial regression are used to identify and profile segments.

Findings: Positively orientated consumers (42\% of respondents) purchase ethical products more so because of reasons relating to impact, health, personal relevance, and quality. Negatively orientated consumers (34\% of respondents) reject ethical alternatives based on reasons relating to indifference, expense, confusion, and scepticism. A third segment is ambivalent in their behaviour and reasoning; they perceive ethical purchasing to be effective and relevant, but are confused and sceptical under what conditions this can occur.

Limitations: Preferences were elicited using an online survey rather than using real market data. Though the task instructions and methods used attempted to minimise social-desirability bias, the experiment might still be subject to its effects.

Implications: Competitive positioning strategies can be better designed knowing which barriers to ethical purchasing are more relevant. The paper challenges the benefits of altruistic-based positioning and outlines shortcomings in communication about ethical products, including those relating to product labelling.

Originality: This research examines an extensive list of reasons for and against ethical purchasing used by a general population of consumers. By forcing respondents to make trade-offs, this is the first study quantifying the relative importance of reasons utilised by consumers. It also highlights the value in using cluster analysis on best-worst scores to identify underlying segments.

Keywords: ethical consumption; reason-based choice; best-worst scaling; relative importance; segmentation; green marketing.

Paper type: Research paper 


\section{Introduction}

Ethical consumerism is defined as the intentional purchase of products considered to be made with minimal harm to humans, animals, and the natural environment (see, Auger et al., 2003; Bray et al., 2011; Papaoikonomou et al., 2012). Consumers are increasingly concerned about their consumption in this regard (Bonini and Oppenheim, 2008; The Co-operative Group, 2012). Over 50\% of consumers polled by Nielsen in 2013 in 58 countries claimed to be willing to pay more for products from socially responsible companies (Nielsen, 2013). In terms of buying behaviour, the growth of ethical consumerism in the last decade has been considerable. For example, ethical spending in the UK has increased by 33\% from 2005 to 2011, to represent a total market value of $£ 47.2 \mathrm{bn}$ (The Cooperative Group, 2012).

Ethical products, however, represent a small proportion of overall sales. In the US, organic food sales represented $4 \%$ of total food sales in 2010; however, this figure was $12 \%$ within the fruit and vegetable category, which represents 39.7\% of total organic food value (Organic Trade Association, 2011). In Europe, the highest market share for organic food occurs in Denmark (6\%) and Austria (5.3\%) (The World of Organic Agriculture, 2009). The market share for fair trade coffee has been estimated to be around 3.8\% in 2007 (Locke et al., 2010). In the non-food sector (e.g., supplements; clothing; personal care), organic products in the US made up $0.5 \%$ of total sales in 2010 (Organic Trade Association, 2011). Green laundry detergents and household cleaners in the US represent around two to three percent of sales (Bonini and Oppenheim, 2008; Packaged Facts, 2010). Growing faster than all professionally managed investment assets, Sustainable Responsible Investment (SRI) strategies represent 10\% of monies under management in Europe (Eurosif, 2010) and $11.2 \%$ of monies managed in the US (US SIF Foundation, 2012). In the green car market, the UK has seen a 28.6\% growth rate during 2011 (The Co-operative Group, 2012). Whilst US electric vehicles sales increased by $13.4 \%$ during 2012, this represents $3.4 \%$ of total new vehicles sold 
(Electric Drive Transportation Association, 2013). In general, whilst demand grows across many markets, ethical products meet only the buying needs of a small niche (Devinney et al., 2010).

Consumers purchase ethically for a range of reasons including perceptions about their positive impact on ones' self-identify and health, and the lives of others (e.g., Carrigan et al., 2004;

Griskevicius et al., 2010). However, even amongst the most ethically orientated consumers the ability to buy ethically on all occasions verges on the mythical (Devinney et al., 2010). Some studies consider why consumers do not always choose ethical options (e.g., Chatzidakis et al., 2007; Bray et al., 2011; Öberseder et al., 2011). The Institute of Grocery Distribution (IGD) reports the top four barriers to ethical shopping are expense, availability, trust and education (see, The Grocer, 2008).

It has been found that when decisions involve rejecting (choosing) options, negative dimensions loom larger (smaller) than positive dimensions (Shafir, 1993). Applied to ethical purchasing, those consumers continually rejecting ethical options might overtly utilize negative reasoning to discount ethical alternatives to simplify decisions and to maintain a status quo. For example, a consumer who rejects recycled toilet paper and chooses non-recycled alternatives might focus more on negative aspects of using recycled material, such as those relating to quality concerns; an ethical consumer might instead focus on its positive environmental impact. In general, segments of consumers might differ in their reasoning when evaluating ethical products; if this is the case, an aggregate approach to understand reason-based ethical choices will be inadequate (Hutchinson et al., 2000).

The aim of this research is to quantify the relative importance of reasons that consumers use in choosing and rejecting ethical products and account for how this differs across various segments. Our research does not focus directly on establishing the relative preference weight or willingness to pay for specific ethical attributes (e.g., biodegradable packaging; fair-trade labels) (e.g., Auger et 
al., 2003; Didier and Lucie, 2008). Instead, we emphasise the reasons that matter most in determining why ethical products, which may incorporate several such attributes to establish a clear positioning, will or will not be purchased. Our research contributes to the literature by presenting a hierarchy of motivational criteria that quantifies and distinguishes between reasons supporting ethical and non-ethical consumption. This research informs product differentiation and communication strategies targeting ethical consumers and outlines which barriers to ethical consumerism require greater attention by researchers, marketers, consumer groups and policy makers.

The remainder of the paper is organized as follows. First, we examine literature on reason-based choices, which motivates our consideration of valance of reasons in ethical consumerism. Second, we outline the qualitative research conducted that we use in conjunction with the literature reviewed to establish a taxonomy of reasons for (non)ethical purchasing. Third, we describe an online survey incorporating a best-worst scaling (BWS) task that quantifies the relative importance of these reasons. Fourth, we cluster analyse the BWS scores to identify three segments, which we relate to category-specific purchase behaviour and socio-demographics. Finally, we discuss the research findings, limitations, and future research opportunities.

\section{Reasons-Based Choices}

The concept of reason-based choice (see, Shafir 1993; Shafir et al., 1993) suggests that decision makers seek reasons to resolve conflict, with greater weight given to positive features in a choice task, whilst greater weight is given to negative features in a rejection task. For example, Shafir (1993) demonstrates that respondents considering vacations focused on the gorgeous beaches in making a booking, but focused on the lack of nightlife when ruling out options. Winchester et al. (2008) finds that positive (negative) beliefs about a brand contribute to increasing the propensity to purchase (reject) a brand. Ganzach (1995) explains that because choosing involves greater 
commitment than rejection, greater weight is given to the negative dimensions of the impoverished alternative. Wedell (1997) argues that a greater need for justification in choice leads to weighting of attribute differences. Each explanation highlights how reasons with varying valance are utilised differently in choosing and rejecting options.

Mercier and Sperber (2011) stress the importance of understanding reasoning due to its impact on devising and evaluating arguments that help justify decisions. Both prior to and following decisions, consumers tend to focus on a chosen option's advantages and distort information about alternatives (Russo et al, 1996; Festinger, 1957), such that even trivial attributes can be used to justify choices (e.g., Brown and Carpenter, 2000). Reasons, therefore, have an iterative impact on choices by functioning as antecedents, consequences and targets to enable clearer justification for decisions (Kivetz, 1999).

In the present context, the aforementioned literature suggests that any account of ethical consumerism should recognise that consumers' existing reasoning about ethical products can distort their evaluation as well as any new information provided about them. We argue that some consumer segments focus on the positive reasons supporting ethical consumerism, given that they more often choose ethical products; similarly, other consumers place greater weight on the negative aspects of ethical consumerism to more easily reject ethical products from their consideration sets. By not accounting for these differences, the relative weight given to the reasons for ethical and nonethical purchasing will be distorted. In the following section, we consider the prior literature examining the different reasons consumers use to choose and to reject ethical products.

\section{Literature Outlining Consumers’ Reasons For and Against Ethical Consumerism}

\subsection{Consumers' reasons for supporting the practice of ethical consumption}

Perceived Consumer Effectiveness (PCE) 
Several researchers identify that consumers choose ethical products because they believe their production, consumption and disposal minimises harm to humans, animals or the environment (e.g., Carrigan and Attalla, 2001; Bray et al., 2011; Hoffmann and Hutter, 2012). Each individual action, though small, can thereby be consequential for a collective ethical purchase movement (Carrigan et al., 2004). Similarly, some consumers act strategically by boycotting companies with questionable ethical practices and rewarding socially responsible companies through "buycotts" (Hoffmann and Hutter; 2012). Such behaviour is consistent with the concept of Perceived Consumer Effectiveness (PCE), which was originally proposed by Kinnear et al. (1974) to explain differences in ecological concern by highlighting the variation in beliefs that individual's hold about the impact of their isolated efforts. Other researchers find that PCE positively impacts ethical attitudes and behaviours (e.g., Berger and Corbin, 1992). Indeed, even when environmental concerns are high, empowerment concerns may impede actions (Cleveland et al., 2005).

Values, norms and social identity

Personal norms and altruistic values are important in explaining why individuals are motivated by personal obligation over self-interest. For example, Stern’s Value-Belief-Norm Theory (Stern et al., 1999) suggests that individuals can feel obligated, via a personal norm activation process, to support movements that reduce threats to valued objects. There is also evidence indicating that ethical choices are guided by principles underwritten by social norms and moral principles that reinforce personal values (e.g., Shaw et al., 2005; Pasewark and Riley, 2010; Davies et al., 2012). Social identify theory further suggests a positive self-concept can be achieved through relevant social group membership (Tajfel and Turner, 1979). Several collective forms of ethical consumption (e.g., cooperatives; 'carrot mobs') can be motivated by social identity (Hoffmann and Hutter, 2012; Papaoikonomou et al., 2012). Religious groups can shape ethical consumption by acting as a normative influence on particular practices (e.g., vegetarianism) and heighten awareness about moral issues, such as those addressed by fair trade (Shaw and Clarke, 1999). Willingness to 
comply with others in buying ethically might occur against consideration of personal attitudes (Vermeir and Verbeke, 2006) and even information about the ethical behaviour of strangers can be influential (Goldstein et al., 2008).

\section{Self-protection and other personal benefits}

The reported extensive information seeking and choice deliberation of ethical consumers (Shrum et al., 1995) has been attributed to self-protection (e.g., Teisl et al., 2008). For example, health concerns have found to be more important than other considerations, including animal cruelty in the context of reducing meat consumption (Richardson et al., 1995), environmental concerns in explaining organic food demand (Bonini and Oppenheim 2008), and as a motivating concern among subscribers to the magazine, Ethical Consumer (Shaw and Clarke 1999). Several researchers suggest that some consumers believe that ethical products can be of a higher quality (e.g., Strong, 1996), including a perception that practices such as free-range farming can improve taste (Bray et al., 2011). Ethical purchasing can communicate status, particularly in conspicuous consumption scenarios; in being able to self-sacrifice, it can signal a consumers' wealth (Griskevicius et al., 2007; 2010). Similarly, ethical consumers are often more knowledgeable information seekers and so valued as opinion leaders (Shrum et al., 1995). In this manner, it is difficult to separate the personal benefits of this role (see, Rose and Kim, 2011) from altruistic motivations highlighted in the previous section.

\section{Improved information about and availability of ethical alternatives}

Many marketplace changes have meant that concerns about the effort to purchase ethical products (see, Carrigan and Attalla, 2001; Vermeir and Verbeke, 2006) are less significant (Bray et al., 2011). The wider availability of ethical products in stores — such as Tesco and Sainsbury's in the UK (Strong, 1996) and Wal-Mart in the US (Oosterveer et al., 2007) — has allowed them to be viewed as viable options alongside mainstream alternatives. Online retailing enables many companies to attract ethical consumers and ship purchases directly to them in a profitable manner. 
Concerns about health and environmental risks are also being informed by improvements in labelling (De Pelsmacker et al., 2005) and ability to access product information online or via mobile phone applications (e.g., GoodGuide, Inc.; PalmOilFree). Consequently, many competitive barriers once forcing ethically positioned products to occupy niche positions (Devinney et al., 2010) are being eroded through new mediums of communication and distribution.

\subsection{Consumers' reasons for rejecting the practice of ethical consumption}

Price-quality concerns and other trade-offs

Ethical alternatives are often viewed as substandard on several performance dimensions (Griskevicius et al., 2010) and much literature indicates that most consumers are unwilling to compromise on price, value, quality, and brand (see, Boulstridge and Carrigan, 2000; Carrigan and Attalla, 2001; Auger et al., 2003; Carrigan et al., 2004; Didier and Lucie, 2008; Auger et al., 2010; Bray et al., 2011). Similarly, in the case of luxuries, Davies et al. (2012) suggests that product satisfaction, self-image, and convenience dominate considerations relative to ethical aspects.

The literature has also highlighted consumers' responses to the general price premium that is borne from producers' costs to address ethical concerns (Auger et al., 2003; De Pelsmacker et al., 2005). In the case of fair-trade, the higher price received by farmers in developing countries and associated control mechanisms warrant such premiums (De Pelsmacker et al., 2005). However, several studies conclude that most consumers are unwilling to pay more for organic and Fair Trade products (e.g., De Pelsmacker et al. 2005; Didier and Lucie 2008). By not utilizing methods that consider these competing perceptions, the value of ethical attributes might have been overstated in previous studies (Auger et al., 2003; 2010).

Lack of information and issues of bombardment 
Many shoppers are passive, guided only by labelling information rather than engaging in any active search about the ethical aspects of products (Carrigan and Attalla, 2001). As such, several researchers indicate that better labelling may aid ethical consumerism (Hartlieb and Jones, 2009; Melbourne Business School, 2012). However, even when information about ethical products can empower decision makers, several researchers suggest that some consumers are more overwhelmed and bombarded — rather than disinterested — in this information (Boulstridge and Carrigan, 2000; Carrigan and Attalla, 2001; Carrigan et al., 2004).

\section{Cynicism and scepticism}

Several researchers find that some consumers are cynical, being unconvinced that ethical choices can minimise harm to humans, animals or the natural environment as intended, representing nothing more than a marketing ploy (Carrigan and Attalla 2001; Bray et al., 2011). Shaw and Shiu (2003) indicate that some consumers believe that premiums paid for ethical alternatives will never reach their intended beneficiaries. In a similar vein, some consumers are willing to accept unethical practices, such as the use of child labour, on the grounds that, whilst unfortunate, this is the norm (Öberseder et al., 2011). This lack of consumer engagement with ethical products due to the belief that their actions will be ineffective (see also, Pelletier et al. 1999) is consistent with the concept of amotivation. Amotivation, proposed by Deci and Ryan (2000) in the context of self-determination theory, suggests some humans lack an intention to behave because they believe their actions will have no impact or that they are incapable of action. These forms of reasoning can also be described in terms of neutralization, a process allowing consumers to insulate themselves from any blame associated with avoiding ethical alternatives (Chatzidakis et al., 2007).

\subsection{Segmentation in ethical consumerism}

The literature presents a range of reasons that consumers use to determine whether to undertake ethical consumption; but some reasons may be utilized more by certain subsets of consumers. The 
role of segmentation in ethical consumerism and concern has received some attention in past literature (e.g., Mainieri et al., 1997; Roberts, 1996; De Pelsmacker et al., 2005; Bezencon and Blili, 2011; Leiserowitz et al., 2012; Wright et al., 2014). For example, Leiserowitz et al.’s (2012) Global Warming's Six America study found significant differences regarding beliefs about the causes, harm and solvability of global warming, ranging from consumers that were alarmed (13\%) or concerned (26\%) to those that were doubtful (15\%) or dismissive (10\%). A more recent study by Wright et al. (2014) into Australian and New Zealanders' views on climate engineering also highlights the value in determining both the negative associations (e.g., uncertainty; risk) and positive associations (e.g., cost effectiveness; long-term sustainability) to better understand overall evaluations; however, they find no differences in these evaluations with respect to various sociodemographics other than that, among New Zealanders, older people tend to be slightly more positive about climate engineering. In terms of ethical consumption, De Pelsmacker et al. (2005) identifies two ethical-based segments, defined by age, education and idealism, with a liking or preference for fair-trade coffee, and who differ from other segments that largely base decisions on flavour or brand. These studies further motivate our research approach to account for heterogeneity in consumers’ reasoning about ethical products.

\section{Methodology}

The research approach involved a combination of qualitative and quantitative research. First, qualitative research was undertaken to build upon the literature and further delineate the reasons for and against ethical purchasing. Second, quantitative research was designed to measure the relative importance of these reasons, and to identify underlying consumer segments with respect to differences in reasoning and behaviour relating to ethical and non-ethical purchasing.

\subsection{Qualitative Research Component: Supplementing a Taxonomy of Reasons}


The qualitative research involved 12 in-depth interviews. The selection of in-depth interviews over focus groups was intended to reduce levels of social desirability bias. Similar to other researchers (e.g., Carrigan et al., 2004), we were also interested in understanding consumers’ experiences voiced in their own terms and social context to develop the BWS task used in the quantitative stage of the research. To ensure broad representation (Teddlie and $\mathrm{Yu}, 2007)$, three adult participants active in household purchases were chosen to represent each of the four combinations created by gender (male; female) and two age groups (less than 35; 35 or above). Several projective techniques were used to further reduce social desirability bias, including Kelly’s Repertory Grid (see Beail, 1985), the Mason Haire technique (Haire, 1950), and cartoon completion (Kvale, 1996). Stimulus materials consisted of samples and photos of competing ethical and non-ethical products, about which respondents noted differences in features, performance, and positioning. In the adapted version of Haire's projective technique, respondents were asked to describe the shopper utilizing two different shopping lists. Respondents were presented with pictures of different supermarket chains (e.g., popular mainstream; one known for offering a higher number of specialty lines, including organic fresh foods) and were asked to describe the typical consumer of each retailer, including their reasons for shopping at each outlet. Interviewees were also asked to picture receiving a gift bought from a well-known ethical retailer and to describe the thoughts of the giver and the receiver. During each stage, the interviewer used various probing techniques to understand how participants viewed ethical and non-ethical consumers.

The qualitative data was content analysed and coded in terms of a taxonomic approach (Spradley, 1979). Identifying statements were classified in terms of reference to choosing or rejecting ethical products. These statements were then coded using overarching metathemes informed by the literature or, as discussed below, into additional classifications emerging from the data. As such, the analysis was largely taxonomic rather than thematic as it proceeded to identify a listing of what reasons consumers used as opposed to questions of why these reasons emerged (Morse, 2008). 
In general, the responses confirmed that consumers employ those reasons used for and against ethical consumption as documented in the literature. In addition, some participants mentioned the innovativeness of ethical products, which seldom appears in the literature as a motivating reason for ethical purchases. The other additional (negative) reasons identified, or those that were further elaborated upon by participants, were:

a. Trialability: Distinctions were made between the perceived monetary risk required to trial an ethical product over and above any long-term concerns about product performance;

b. Packaging: Ethical products were often described as unattractive and unappealing in this regard.

c. Indifference: Different to the notion of scepticism about the impact of ethical products, some participants expressed complete indifference, not caring one way or the other about the issues addressed by ethical consumerism.

d. Availability: Participants made distinctions between concerns about locating products within a store (e.g., specialty section within a supermarket) and across retailers (e.g., only carried at specialty stores).

e. Confusion: Whilst participants noted improvements in the labelling and information surrounding ethical alternatives, there was confusion as to what constitutes a product as being labelled ethical.

f. Stigma: Some participants reported that, in some cases, ethical consumers are negatively marginalized or judged in terms of inappropriate stereotypes.

Table 1 summarizes the reasons used by consumers in making decisions for and against ethical consumption as reported in the literature or additionally identified through the in-depth interviews. Each reason is presented in terms of an exemplary statement of the taxonomic coding scheme developed that captures a combination of expressions that participants used. In the remaining sections, the relative importance of each reason in shaping ethical consumption behaviour is quantified and distinctive segments are identified in this regard. 
Insert Table 1 about here

\subsection{Quantitative Research Component: Best-Worst Scaling of Reasons}

The purpose of the best-worst scaling (BWS) task was to quantify the level to which the 25 reasons listed in Table 1 are utilized by a representative sample of consumers to purchase or to reject ethical options. BWS was first introduced by Finn and Louviere (1992) to assess the relative importance of food safety against other areas of public concern; whilst, Marley and Louviere (2005) provide mathematical proofs of its measurement properties. The method is attractive as it forces respondents to discriminate among reasons, rather than to rate each one-at-a-time, thereby revealing their relative importance (Louviere and Islam, 2008). BWS has been applied in contexts such as consumer behaviour (e.g., Louviere and Islam, 2008), health economics (Lancsar et al., 2007), personality research (Lee et al., 2008), and education (Burke et al., 2013). In ethical consumer research, Auger et al. (2007) used BWS to examine the relative valuation of ethical and social issues, such as concerns for human rights relative to concerns about genetically modified foods.

Responses were collected from 200 adults involved in household purchases accessed via an Australia-wide online panel provider (see Table 2). Regardless of prior ethical purchasing rates, each respondent evaluated 10 sets consisting of four reasons for choosing and rejecting ethical products. From each set, respondents indicated first, which reason they predominantly used in choosing, or not choosing, to purchase ethically, and second, which they utilized the least. To obtain a full ranking of the four reasons, respondents then nominated the reason they most utilized in decisions to purchase ethically or not, out of the two remaining items.

Insert Table 2 about here 
A Balanced Incomplete Block Design (BIBD) determined the different combinations of reasons each respondent evaluated to maximize the statistical information that could be gathered efficiently relative to displaying randomly selected subsets of reasons (Street and Street, 1987). The 25 reasons were arranged into 50 sets of four items with each appearing eight times and paired with each other reason once. This allowed us to gather full-rank information of all four items with three questions only (best-worst-best). Other designs involving a larger number of items per set (e.g., 25 sets of five items) require additional questions (e.g., second worst) to obtain full rank information; those with fewer items per set (e.g., 100 sets of three items) require two questions only (best and worst), but gather less trade-off information per set. Hence, the master design chosen provided a desirable balance between the demands of the task and maximising information about item-by-tem comparisons. From this master design, five versions each consisting of 10 sets, were generated based on making random draws, without replacement. The final design was selected so that within each version, every reason was evaluated at least once and, over the set of a thousand random draws conducted, maximised the D-efficiency of the design within each version (see, Kuhfeld et al., 1994). Forty respondents were randomly assigned to each of the five versions of the master design, resulting in a total of 200 respondents.

\section{Analysis and Results}

\subsection{Aggregate Best-Worst Scores for Reasons For and Against Ethical Consumption}

Individual-level best-worst scores for each reason were calculated using the ranking expansion method (see, Louviere et al., 2008). On average, the reason most commonly cited to explain ethical purchasing is that it helps make a difference (i.e., impact), as indicated by the highest mean BWS score in Table 3. The most commonly cited reason for not purchasing ethically, on average, relates to confusion about what makes a product ethical. Those reasons associated with a higher standard 
deviation are associated with greater heterogeneity among the sample in terms of their use and this is explored in the next section.

Insert Table 3 about here

\subsection{Differences in Reasoning: Cluster Analysis of Best-Worst Scores}

The issue of aggregation bias in BWS scores and how this can be addressed by clustering techniques has previously been demonstrated by Lockshin and Cohen (2011) in the study of crossnational wine choices. In the present study, a cluster analysis on the BWS scores allowed the identification of distinct segments such that, within each, its members hold a common, but unique approach to reasoning about ethical purchases. A two-stage clustering procedure was used: the first stage involved a hierarchical clustering procedure — Ward's method — to determine the number of clusters (Hair et al., 2010). The choice of three clusters was based on improvements in the agglomeration schedule, confirmed by visual inspection of the dendrogram and an observable elbow in a scatter plot of the number of clusters against the distance clusters were combined (Mooi and Sarstedt, 2011). To check for stability, several distance measures and agglomeration procedures were used, providing further support for a three cluster solution. In the second stage, k-means clustering was used to identify three distinctive homogenous clusters by minimizing within-cluster variation in relation to the BWS measures (see Table 4).

Cluster 1 (83 respondents or $41.5 \%$ of the sample) represents consumers who reason that ethical purchasing will make a difference, is a healthier choice, is of general relevance to them, and that purchases are of a higher quality. If they do not purchase ethically, it is based on reasons relating to the effort to locate ethical alternatives (within and between stores) and their expense. Cluster 2 (33.5\% of the sample) give little thought to ethical products, reasoning that ethical options are too 
expensive. They are confused by, and sceptical about, what makes a product ethical. If they do purchase an ethical product, it is because of reasons based on personal benefits relating to health and cost savings. Cluster 3 (25\% of the sample) are ambivalent in their reasoning about ethical products. They care about the issues that ethical consumption addresses, believing that it can make a difference. However, they are also confused and sceptical about the information and impact surrounding ethical purchasing. Hence, to aid in discussion and interpretation, we re-label the clusters in terms of three types of orientations: positive (cluster 1), negative (cluster 2), and mixed (cluster 3).

Insert Table 4 about here

ANOVA was performed on the cluster solution to identify which reasons were significant in explaining differences in the mean scores of each cluster (see Table 4). It revealed that differences between segments is driven by reasoning regarding the impact of ethical purchasing $(F=97.5$; $\mathrm{p}=.0000$ ). Following this, segments are predominantly determined by differences in the utilization of reasons for not purchasing ethically, as represented by the larger F-statistics demonstrating significant differences among these sets of BWS scores.

\subsection{Relationship between Reason-Based Segments and Category Specific Purchase Behaviour}

Contingency analysis was undertaken to confirm whether each segment is associated with particular levels of ethical behaviour in a variety of product categories as expected. To do so, in relation to only those product categories that they regularly purchase from, respondents indicated how frequently they purchase an ethical alternative (never; rarely; occasionally; most or all of the time). The selection of product categories to elicit responses about ethical purchase behaviour was based on those frequently examined in previous studies, including coffee (e.g., De Pelsmacker et al., 
2005), chocolate (e.g., Didier and Lucie, 2008) and chicken (e.g., Teisl et al., 2008). The selection also included examples of ethical products that respondents specifically mentioned in the qualitative research component, including recycled printer paper and dolphin safe tuna. The list was supplemented with categories frequently appearing in online guides and mobile phone applications (e.g., GoodGuide, Inc.) informing consumers about ethical purchases.

Insert Table 5 about here

In 13 out of the 17 product categories examined, the relationship between reasoning and ethical purchase behaviour was significant and consistent with expectations (see Table 5). Figure 1 further describes those respondents who never, or rarely, purchase an ethical option from a product category for which they frequently purchase from. It confirms that those rejecting ethical options are more likely to be from the negatively orientated cluster, with behaviours based on reasons relating to indifference, confusion, expense and scepticism. Figure 2 illustrates that those buying ethical products are more likely to be from the positively orientated cluster, who buy ethically more so because of reasons relating to impact, health, and relevance.

Insert Figure 1 and 2 about here

Respondents also reported their ethical purchasing behaviour among infrequently or long-term purchased goods associated with product categories from which they had previously bought. Given that a respondent had chosen an ethical option in such cases, the likelihood that this respondent is positively orientated in their reasoning about ethical products is highest in all but one case (solar power heating) (see Table 6). 
In summary, the reasons identified from the literature and qualitative research, and subsequently quantified in terms of relative importance for each orientation, are confirmed to be largely deterministic of market behaviour in relation to variations in ethical consumerism. In the next section, we describe each cluster in more detail, using various socio-demographic measures which allow potential segmentation strategies to be considered in terms of measurable and identifiable variables (Lin, 2002).

\subsection{Socio-Demographic Profile of Different Ethical Orientations}

To create a descriptive profile of each segment, we estimated a Multinomial Logit Model (MNL) with cluster membership as the dependent variable, and selected socio-demographics as predictors. It was intended to confirm that each reason-based segment is reflective of several sociodemographics that correlate with various ethical attitudes and behaviours as demonstrated in previous studies (e.g., Roberts, 1996; Mainieri et al., 1997; De Pelsmacker et al., 2005). The resulting model predicts that those with positive orientations are more likely to be female, be aged 55 or more, be tertiary educated, and support a liberal political party rather than a labour political party (see Table 7). Those with negative orientations are more likely to be male, be aged 35 to 54 , less likely to hold a graduate degree, and be supportive of a liberal rather than a labour or green political party. Those with more mixed orientations are more likely to be female, hold a graduate degree, and support the labour or the Greens parties, as opposed to the liberal party.

Insert Table 7 about here 


\section{Discussion}

This paper quantified which reasons consumers use to choose and reject ethical products and demonstrates how this differs across ethical and non-ethical consumer segments. The results indicate that whilst many consumers would like to make a difference and do care about the issues that ethical products address, the key barriers to ethical consumption among ambivalent consumers relate to confusion and scepticism. These results imply that there is a need to create clarity for consumers in regard to how their consumption makes a difference in minimising harm to humans, animals or the environment in the production, consumption and disposal of various products. As such, efforts to address issues of uncertainty surrounding perceived consumer effectiveness (Kinnear et al., 1994; Cleveland et al., 2005) may shift consumers with an ambivalent view about the benefits of ethical consumption to one that is more positively orientated towards it. For firms offering ethical products, there may be strategic benefit in communicating more extensive information, such as through clearer labelling, to help consumers better learn about how their ethical purchases create real differences (Hartlieb and Jones, 2009). Whilst some studies have found mixed reactions to organic and fair-trade labelling and associated quality concerns (e.g., Strong, 1996; Didier and Lucie, 2008), the present study found these concerns were outweighed by the value in the information that labelling can provide.

Consumers seek relevant information from credible sources. Subsequently, the formal regulation of labels could be one means to address issues of scepticism and trust (see also, Bezencon and Blili, 2010). More generally, improving information about the tangible benefits of ethical purchasing may fall upon various organisations, including non-government entities, researchers and the media. For example, a lack of certification structure and agreed standards has created confusion about the effectiveness of various carbon offset providers; in turn, Dhanda and Hartman (2011) offer an approach to effectively compare providers. The role of third-parties and technology is also exemplified in the growth of mobile phone applications providing ethically related information. 
Such strategies must be considered against whether consumers feel overburdened by messages of ethical consumption (e.g., Boulstridge and Carrigan, 2000; Carrigan and Attalla, 2001), although in the current study, this appeared to be relatively less concerning.

Our results further indicate that reasons used for and against ethical purchasing are less related to social aspects (e.g., fitting with peers, opinion leadership, social status concerns). Instead, reasoning relates more to issues of well-being, such as health, even among ethical consumers. This offers a more individualistic perspective on ethical consumption than one emerging primarily from themes of altruism or collectivism, which in turn has positioning implications for ethical products and related supply practices. For example, concerns about GM food options and hormone free chicken farming have often been related back to environmental impact and animal welfare (Teisl et al., 2008). The present research, however, suggests that perceptions about how such practices impact personal wellbeing will feature more highly in shaping consumer behaviour.

The research identified that the number one reason for why negatively orientated consumers do not purchase ethically is because of indifference, namely that they do not give ethical products much thought. This reason is in addition to the amotivation of some consumers towards ethical purchasing, who perceive their actions to be inconsequential (Pelletier et al., 1999; Deci and Ryan, 2000). The promotion of ethical products using messages that solely communicate on ethical dimensions to those who do not care to listen seems a futile one. Such a myopic communication strategy goes against the elementary premise of product strategy: sources of product differentiation must be relevant to consumers to create competitive advantage. This suggests the benefits of ethical products should also be presented in terms that are relevant to these consumers. For example, many consumers will not primarily buy a hybrid vehicle because it helps the environment or because it helps communicate their concerns to others (Griskevicius et al., 2007), but may consider it to reduce fuel costs (Griskevicius et al., 2010). In the present research, we find that if negatively orientated consumers do buy an ethical option, it is predominantly based on reasons relating to cost 
savings and benefits to their own health. Similarly, the focus on monetary savings with rising electricity prices, could explain the relatively higher uptake of solar heating among the negatively orientated consumers observed in this study.

We profiled segments to predict who would be more likely to hold one type of ethical orientation in terms of reasoning and behaviour more so than another. The lack of significance for some predictors in our model is consistent with previous research, which reports rather mixed findings about the relationship between socio-demographics and ethical attitudes and behaviours (e.g., Roberts, 1996; Mainieri et al., 1997; Hoffman, 1998; Auger et al., 2003; De Pelsmacker et al., 2005; Wright et al., 2014). Our findings, however, support the general consensus that targeting females in ethical consumption settings will have greater success (Roberts, 1996; Mainieri et al., 1997; De Pelsmacker et al., 2005). The expectation that those who support green political parties would hold distinctly positive orientations was not supported. Whilst some of this can be explained by an inability to detect significant differences with a small subset of respondents $(n=26$ green voters), it is worthwhile considering that the viewpoints of consumers do not always translate into purchase behaviours.

\section{Limitations and Avenues for Future Research}

One limitation of this research is that it did not examine whether reasons for ethical and non-ethical consumption are more relevant to specific product categories. For example, the importance of health concerns might generalize across a number of categories (e.g., food; detergents), whilst concerns about social stigma might be more relevant to categories involving conspicuous consumption (Griskevicius et al., 2007; 2010). Similarly, the understanding of how consumers evaluate ethical services, including reasons leading to non-adoption, deserves attention in future research. We showed a relationship between the reason-based segments identified and the propensity to purchase carbon offsets in buying airline tickets. Indeed, Holden (2009) argues that 
consumers' play a pivotal role within the sustainable tourism and aviation markets to instigate positive change. In other research, Goldstein et al. (2008) demonstrate the role of social norms in environmental conservation (e.g., via towel use) in hotels. In a similar vein, Harmon and Auseklis (2009) point to the merits of sustainable information technology service practice, but indicate that little is known about consumers' valuation of such services.

Another limitation of our study is that respondents might have overstated their use of positive reasons in evaluating ethical products or the extent to which they purchase them. However, the motivation for using BWS and related BIBD design was to encourage trade-offs among reasons. Eliciting trade-offs among socially desirable elements by embedding these in the response task has been successfully used in various settings (e.g. Finn and Louviere, 1992), including in the context of measuring the value of ethical features (Auger et al., 2003; 2010). Similarly, measures of relative importance were intended to maximise discrimination among responses and comparisons of purchase behaviour across segments were based on conditional probabilities.

Respondents undertook ten choice sets involving a best-worst-best ranking task, so the findings may be subject to the impact of respondent fatigue. Empirically, however, there is a strong correlation between what respondents' state as important in choice experiments and models based on real market settings with many differences often attributable to variability in the measures (see, Louviere, 2001). Nonetheless, future research could investigate how various reasons behind ethical decision making correlate with real levels of ethical purchasing. To do so, the taxonomy of reasons we identified could be used to categorise the positioning of existing ethical products. This categorisation could then be used to study a number of outcomes, such as how demand differs across various segments of consumers. Similarly, a real shopping experiment could be designed based on this same categorisation, but could be lab-based to adequately account for the impact of other variables such as price, availability and shelf-positioning. 
Finally, we described each of the three reason-based segments using socio-demographic variables. Their use is attractive to marketers because they are measurable and identifiable (Lin, 2002), but other segmentation variables, such as psychographic characteristics or traits, could be useful as demonstrated in other ethical consumer research (e.g., Auger et al. 2003; Rallapalli et al. 1994; De Pelsmacker et al. 2005).

\section{Research Implications and Conclusion}

This research informs researchers and practitioners as to what reasons relating to the benefits and shortcomings of ethical products are most important in shaping ethical and non-ethical choices. Whereas previous literature has focused on attitudes towards and preference for specific ethical attributes of products (e.g., Auger et al., 2003; Didier and Lucie, 2008), we quantify the underlying reasons for why such attributes may be more or less attractive. The research confirms suggestions that a large segment of consumers are positively orientated towards ethical purchasing (e.g., Davies et al., 2012). The present research suggests, however, the merits in understanding the cynicism of some non-ethical consumers rather than ignoring their views, or waiting for their views to somehow change. Our findings offer clearer direction to marketers about how to better position their products and the types of communication strategies in supporting this endeavour. The research also suggests which barriers require greater attention relative to others in encouraging support for a variety of consumer groups that aim to minimise harm to people, animals and the environment.

The study also provides empirical evidence for how BWS scores can be subject to the same levels of aggregation bias present in many other measures. In turn, we once again highlight the valuable insights of identifying underlying consumer segments with respect to BWS task derived measures, as Lockshin and Cohen (2011) have previously demonstrated in the context of wine choices. Using such an approach in the present context of ethical consumerism, our study provides a quantitativebased hierarchy of motivational criteria distinguishing between those buying ethically and those 
who do not. It highlights those aspects of ethical consumerism requiring greater scrutiny, such as investigating substantive questions about what drives confusion and scepticism among non-ethical and ambivalent consumers and how this can be addressed. 


\section{REFERENCES}

Auger, P., Burke, P., Devinney, T. M. and Louviere, J. J. (2003), "What will consumers pay for social product features?”, Journal of Business Ethics, Vol. 42 No. 3, pp. 281-304.

Auger, P., Devinney, T. M. and Louviere, J. J. (2007), “Using best-worst scaling methodology to investigate consumer ethical beliefs across countries”, Journal of Business Ethics, Vol. 70 No. 3, pp. 299-326.

Auger, P., Devinney, T. M., Louviere, J. J. and Burke, P. F. (2010), “The importance of social product attributes in consumer purchasing decisions: a multi-country comparative study”, International Business Review, Vol. 19 No. 2, pp. 140-59.

Beail, N. (ed) (1985), Repertory Grid Technique and Personal Constructs: Applications in Clinical and Educational Settings, Croom Helm, London.

Berger, I. E. and Corbin, R. M. (1992), "Perceived consumer effectiveness and faith in others as moderators of environmentally responsible behaviors”, Journal of Public Policy \& Marketing, Vol. 11 No. 2, pp. 79-89.

Bezencon, V. and Blili, S. (2010), “Ethical products and consumer involvement: what’s new?”, European Journal of Marketing, Vol. 44 No. 9/10, pp. 1305-1321.

Bonini, S. and Oppenheim, J. (2008), “Cultivating the green consumer”, Stanford Social Innovation Review, Vol. 6, No.4 pp. 56-61.

Boulstridge, E. and Carrigan, M. (2000), “Do consumers really care about corporate responsibility? Highlighting the attitude behaviour gap”, Journal of Communication Management, Vol. 4 No. 4, pp. 355-363.

Burke, P. F., Schuck, S., Aubusson, P., Buchanan, J., Louviere, J. J., and Prescott, A. (2013), "Why do early career teachers choose to remain in the profession? The use of best-worst scaling to quantify key factors”, International Journal of Educational Research, Vol. 62, pp. 259268. 
Bray, J., Johns, N. and Kilburn, D. (2011), “An exploratory study into the factors impeding ethical consumption”, Journal of Business Ethics, Vol. 98 No. 4, pp. 597-608.

Brown, C. L. and Carpenter, G. S. (2000), "Why is the trivial important? A reasons-based account for the effects of trivial attributes on choice”, Journal of Consumer Research, Vol. 26 No. 4, pp. 372-385

Carrigan, M. and Attalla, A. (2001), “The myth of the ethical consumer - do ethics matter in purchase behaviour?”, Journal of Consumer Marketing, Vol. 18 No. 7, pp. 560 - 78.

Carrigan, M., Szmigin, I. and Wright, J. (2004), “Shopping for a better world? An interpretive study of the potential for ethical consumption within the older market”, Journal of Consumer Marketing, Vol. 21 No. 6, pp. 401-17.

Chatzidakis, A., Hibbert, S. and Smith, A. (2007), “Why people don’t take their concerns about fair trade to the supermarket: the role of neutralisation”, Journal of Business Ethics, Vol. 74 No. 1, pp. 89-100.

Cleveland, M., Kalamas, M. and Laroche, M. (2005), “Shades of green: linking environmental locus of control and pro-environmental behaviors”, Journal of Consumer Marketing, Vol. 22 No. 4, pp. 198-212.

Davies, I.A., Lee, Z. and Ahonkhai, I. (2012), “Do consumers care about ethical luxury?”, Journal of Business Ethics, Vol. 106 No. 1, pp. 37-51.

Deci, E. L., and Ryan, R. M. (2000), "The" what" and" why" of goal pursuits: human needs and the self-determination of behaviour”, Psychological Inquiry, Vol. 11 No. 4, pp. 227-268.

De Pelsmacker, P., Driesen, L. and Rayp, G. (2005), “Do consumers care about ethics? Willingness to pay for fair-trade coffee”, The Journal of Consumer Affairs, Vol. 39 No. 2, 363 - 385.

Devinney, T. M., Auger, P. and Eckhardt, G. M. (2010), The Myth of the Ethical Consumer. Cambridge University Press, Cambridge, United Kingdom. 
Dhanda, K. K., and Hartman, L. P. (2011), “The ethics of carbon neutrality: a critical examination of voluntary carbon offset providers”, Journal of Business Ethics, Vol. 100 No. 1, pp. 119149.

Didier, T. and Lucie, S. (2008), “Measuring consumer's willingness to pay for organic and Fair Trade products”, International Journal of Consumer Studies, Vol. 32 No. 5, pp. 479-90. Electric Drive Transportation Association (2013), “Electric drive vehicle sales figures (U.S. Market)”, available at: http://electricdrive.org/index.php?ht=d/sp/i/20952/pid/20952 (accessed 31 October 2013).

Eurosif (2010), “The European SRI Study 2010”, European Sustainable Investment Forum, available at: http://www.eurosif.org/research/eurosif-sri-study/2010 (accessed 6 November 2013).

Fair Trade USA (2013), “Fair Trade USA Almanac 2012”, available at: http://www.fairtradeusa.org/sites/default/files/2012_Fair-Trade-USA_Almanac.pdf (accessed 25 October 2013).

Festinger, L. (1957), A Theory of Cognitive Dissonance, Stanford: Stanford University Press. Finn, A. and Louviere, J.J. (1992), “Determining the appropriate response to evidence of public concern: the case of food safety”, Journal of Public Policy and Marketing, Vol. 11 No. 1, pp. 12-25.

Ganzach, Y. (1995), “Attribute scatter and decision outcome: judgment versus choice”, Organizational Behavior and Human Decision Processes, 62, 113-122.

Goldstein, N. J., Cialdini, R. B. and Griskevicius, V. (2008), “A room with a viewpoint: using social norms to motivate environmental conservation in hotels”, Journal of Consumer Research, Vol. 35 No. 3, pp. 472-82.

Griskevicius, V., Tybur, J. M., Sundie, J. M., Cialdini, R. B., Miller, G. F. and Kenrick, D. T. (2007), “Blatant benevolence and conspicuous consumption: when romantic motives elicit 
strategic costly signals”, Journal of Personality and Social Psychology, Vol. 93 No. 1, pp. 85.

Griskevicius, V., Tybur, J. M. and Van den Bergh, B. (2010), “Going green to be seen: status, reputation, and conspicuous conservation”, Journal of Personality and Social Psychology, Vol. 98 No. 3, pp. 392.

Hair, J. F., Black, W. C., Babin, B. J. and Anderson, R. E. (2010),. Multivariate Data Analysis (7e). Prentice Hall, New York. Chapter 8: Cluster analysis.

Haire, M. (1950), “Projective techniques in marketing research”, The Journal of Marketing, Vol. 14 No. 5, pp. 649-656.

Harmon, R. R., and Auseklis, N. (2009), “Sustainable IT services: assessing the impact of green computing practices”, in Portland International Conference on Management of Engineering and Technology (PICMET), Portland Oregon, USA, pp. 1707-1717.

Hartlieb, S., and Jones, B. (2009), “Humanising business through ethical labelling: progress and paradoxes in the UK”, Journal of Business Ethics, Vol. 88 No. 3, pp. 583-600.

Hoffman, J.J. (1998), “Are women really more ethical than men? Maybe it depends on the situation”, Journal of Managerial Issues, Vol. 10 No. 1, pp. 60-73.

Hoffmann, S. and Hutter, K. (2012), "Carrotmob as a new form of ethical consumption: the nature of the concept and avenues for future research”, Journal of Consumer Policy, Vol. 35 No. 2, pp. 215-236.

Holden, A. (2009), “The environment-tourism nexus: influence of market ethics”, Annals of Tourism Research, Vol. 36 No. 3, pp. 373-389.

Hutchinson, J. Wesley., Wagner. A. Kamakura and John G. Lynch Jr. (2000), “Unobserved heterogeneity as an alternative explanation for "reversal" effects in behavioural research”, Journal of Consumer Research, Vol. 27 No. 3, pp. 324-44. 
Kinnear, T. C., Taylor, J. R. and Ahmed, S. A. (1974), “Ecologically concerned consumers: who are they?”, The Journal of Marketing, 20-24.

Kivetz, R. (1999), “Advances in research on mental accounting and reason-based choice”, Marketing Letters, Vol. 10 No. 3, pp. 249-266.

Kuhfeld, W.F., Tobias, R.D. and Garratt, M. (1994), “Efficient experimental design with marketing research applications”, Journal of Marketing Research, Vol. 31 No. 4, pp. 545-557.

Kvale, S. (1996), Interviews: An Introduction to Qualitative Research Interviewing, Sage Productions Inc, Thousand Oaks, San Francisco, CA.

Lancsar, E., Louviere, J.J. and Flynn, T.N. (2007), “Several methods to investigate relative attribute impact in stated preference experiments”, Social Science and Medicine, Vol. 64 No. 8, pp. 1738-1753.

Lee, J. A., Soutar, G.N. and Louviere, J. (2008), “The best-worst scaling approach: an alternative to Schwartz’s values survey”, Journal of Personality Assessment, Vol. 90 No. 4, pp. 335-347.

Leiserowitz, A., Maibach, E., Roser-Renouf, C. and Hmielowski, J. (2012), “Global Warming’s Six Americas”. Yale University and George Mason University. New Haven, CT: Yale Project on Climate Change Communication, available at: http://environment.yale.edu/climatecommunication/files/Six-Americas-March-2012.pdf (accessed 25 September 2013).

Lin, C. (2002), “Segmenting customer brand preference: demographic or psychographic”, Journal of Product and Brand Management, Vol. 11 No. 4, pp. 249 - 268.

Locke, R.M., Reavis, C. and Cameron, D. (2010), “Fair trade coffee: the mainstream debate”, MIT Sloan Management, 08-069, pp. 1-23, available at: https://mitsloan.mit.edu/LearningEdge/CaseDocs/08\%20069\%20Fair\%20Trade\%20Coffee \%20The\%20Mainstream\%20Debate\%20Locke.pdf (accessed 19 September 2013).

Lockshin, L. and Cohen, E. (2011), “Using product and retail choice attributes for cross-national segmentation”, European Journal of Marketing, Vol. 45 No. 7/8. pp. 1236-1252. 
Louviere, J. J. (2001), “What if consumer experiments impact variances as well as means?

Response variability as a behavioral phenomenon”, Journal of Consumer Research, Vol. 28 No. 3, pp. 506-511.

Louviere, J. and Islam, T. (2008), “A comparison of importance weights and willingness-to-pay measures derived from choice-based conjoint, constant sum scales and best-worst scaling”, Journal of Business Research, Vol. 61 No. 9, pp. 903-911.

Louviere, J. J., Street, D., Burgess, L., Wasi, N., Islam, T. and Marley, A. A. J. (2008), “Modeling the choices of individual decision-makers by combining efficient choice experiment designs with extra preference information”, Journal of Choice Modelling, Vol. 1 No. 1, pp. 128163.

Mainieri, T., Barnett, E.G., Valdero, T. R., Unipan, J.B. and Oskamp, S. (1997), “Green buying: the influence of environmental concern on consumer behaviour”, The Journal of Social Psychology, Vol. 137 No. 2, pp. 189-204.

Marley, A.A. and Louviere, J.J. (2005), “Some probabilistic models of best, worst, and best/worst choices”, Journal of Mathematical Psychology, Vol. 49 No. 6, pp. 464-80.

Melbourne Business School (2012), “Call for better labelling to support ethical consumption”, available at:

http://www.mbs.edu/mbshub/Pages/Article/Callforbetterlabelingtosupportethicalconsumptio n.aspx (accessed 9 October 2013).

Mercier, H., and Sperber, D. (2011), “Why do humans reason? Arguments for an argumentative theory”, Behavioral and Brain Sciences, Vol. 34 No. 2, pp. 57-111.

Mooi, E. and Sarstedt, M. (2011), A Concise Guide to Market Research. Springer-Verlag, Berlin Heidelberg.

Morse, J. M. (2008), “Confusing categories and themes”, Qualitative Health Research, Vol. 18 No. 6, pp. 727-728. 
Nielsen (2013), “50\% of global consumers surveyed willing to pay more for goods, services from socially responsible companies, up from 2011”, available at: http://www.nielsen.com/us/en/press-room/2013/nielsen-50-percent-of-global-consumerssurveyed-willing-to-pay-more-fo.html\#sthash.996N9DhT.dpuf (accessed 9 October 2013).

Öberseder, M., Schlegelmilch, B. and Gruber, V. (2011), “Why don’t consumers care about CSR?: A qualitative study exploring the role of CSR in consumption decisions”, Journal of Business Ethics, Vol. 104 No. 4, pp. 449-60.

Oosterveer, P. Guivant, J.S. and Spaargaren, G. (2007), “Shopping for green foods in globalizing supermarkets: sustainability at the consumption junction” in J. Pretty, A.S. Ball, T. Benton, J. Guivant, D.R. Lee, D. Orr, M.J. Pfeffer, and Hugh Ward (Eds.) The Sage Handbook of Environment and Society (pp. 411 - 428). Sage: London.

Organic Trade Association (2011), “OTA’s 2011 Organic Industry Survey”, available at: http://www.ota.com/pics/documents/2011OrganicIndustrySurvey.pdf (accessed 12 October 2013).

Packaged Facts (2010), “Green Household Cleaning Products in the U.S.”, available at: http://www.packagedfacts.com/Green-Household-Cleaning-2554249/ (accessed 31 October 2010).

Papaoikonomou, E., Valverde, M. and Ryan, G. (2012), “Articulating the meanings of collective experiences of ethical consumption”, Journal of Business Ethics, Vol. 110,No. 1. pp. 15-32. Pasewark, W.R. and Riley, M.E. (2010), "It's a matter of principle: the role of personal values in investment decisions”, Journal of Business Ethics, Vol. 93 No. 2, pp. 237-253.

Pelletier, L. G., Dion, S., Tuson, K., and Green-Demers, I. (1999), “Why do people fail to adopt environmental protective behaviors? Toward a taxonomy of environmental amotivation”, Journal of Applied Social Psychology, Vol. 29 No. 12, pp. 2481-2504. 
Rallapalli, K. C., Vitell, S. J., Wiebe, F. A., \& Barnes, J. H. (1994), “Consumer ethical beliefs and personality traits: an exploratory analysis”, Journal of Business Ethics, Vol. 13 No. 7, pp. 487-495.

Richardson, N.J., Shepherd, R. and Elliman, N.A. (1993), “Current attitudes and future influence on meat consumption in the UK”, Appetite, Vol. 21 No. 1, pp. 41-51.

Roberts, J.A. (1996), “Will the real socially responsible consumer please step forward?”, Business Horizons, Vol. 39 No. 1, pp. 79-84.

Rose, P. and Kim, J. (2011), “Self-monitoring, opinion leadership and opinion seeking: a sociomotivational approach”, Current Psychology, Vol. 30, pp. 203-214.

Russo, J. E., Medvec, V. H., and Meloy, M. G. (1996), “The distortion of information during decisions”, Organizational Behavior and Human Decision Processes, Vol. 66 No. 1, pp. 102-110.

Shafir, E. (1993), “Choosing versus rejecting: why some options are both better and worse than others”, Memory and Cognition, Vol. 21 No. 4, pp. 546-556

Shafir, E., Simonson, I. and Tversky, A. (1993), “Reason-based choice”, Cognition, Vol. 49 No. 12, pp. 11-36.

Shaw, D. and Clarke, I. (1999), "Belief formation in ethical consumer groups: an exploratory study”, Marketing Intelligence and Planning, Vol. 17 No. 2, pp. 109 - 120.

Shaw, D., Grehan, E., Shiu, E., Hassan, L. and Thomson, J. (2005), “An exploration of values in ethical consumer decision making”, Journal of Consumer Behaviour, Vol. 4 No. 3, pp. 185200.

Shaw, D. and Shiu, E. (2003), “Ethics in consumer choice: a multivariate modelling approach”, European Journal of Marketing, Vol. 37 No. 10, pp. 1485-1498. 
Shrum, L. J., McCarty, J. A. and Lowrey, T. M. (1995), "Buyer characteristics of the green consumer and their implications for advertising strategy”, Journal of Advertising, Vol. 24 No. 2, pp. 71-82.

Spradley, J. P. (1979), The Ethnographic Interview. New York: Holt, Rinehart and Winston.

Stern, P. C., Dietz, T., Abel, T., Guagnano, G. A. and Kalof, L. (1999), “A value-belief-norm theory of support for social movements: the case of environmentalism”, Human Ecology Review, Vol. 6 No. 2, pp. 81-98.

Street, A.P. and Street, D.J. (1987), Combinatorics of Experimental Design. Oxford University Press , Claredon.

Strong, C. (1996), "Features contributing to the growth of ethical consumerism-a preliminary investigation”, Marketing Intelligence and Planning, Vol. 14 No. 5, pp. 5-13.

Tajfel, H. and Turner, J. C. (1979), “An integrative theory of intergroup conflict”, in W. Austin \& S. Worchel (Eds.), The Social Psychology of Intergroup Relations, Pacific Grove, CA: Brooks/Cole, pp. 33-47.

Teddlie, C. and Yu, F. (2007), “Mixed methods sampling: a typology with examples”, Journal of Mixed Methods Research, Vol. 1 No. 1, pp. 77-100.

Teisl, M.F., Radas, S. and Roe, B. (2008), “Struggles in optimal labelling: how different consumers react to various labels for genetically modified foods”, International Journal of Consumer Studies, Vol. 32, pp. 447-456.

The Co-operative Group (2012), “Ethical Consumer Markets Report 2012”, The Co-operative Group, United Kingdom, available at: http://www.cooperative.coop/PageFiles/416561607/Ethical-Consumer-Markets-Report-2012.pdf (accessed 15 October 2013). 
The Grocer (2008), “The rise and stall of the ethical shopper”, 31 March, available at: http://www.thegrocer.co.uk/topics/the-rise-and-stall-of-the-ethical-shopper/125587.article (accessed 31 September 2013).

The World of Organic Agriculture (2009), “The World of Organic Agriculture, Statistics and Emerging Trends 2009”, Helga, W. and Kilcher, L. (Eds).

US SIF Foundation (2012), “2012 Report on Sustainable and Responsible Investing Trends in the United States”, available at: http://www.ussif.org/files/Publications/12_Trends_Exec_Summary.pdf (accessed 6 November 2013).

Vermeir, I. and Verbeke, W. (2006), “Sustainable food consumption: exploring the consumer “attitude-behavioural intention” gap”, Journal of Agricultural Environmental Ethics, Vol. 19, pp. 169-194.

Wedell, D.H. (1997), “Another look at reasons for choosing and rejecting”, Memory and Cognition, Vol. 25 No. 6, pp. 873-887.

Winchester, M., Romaniuk, J. and Bogomolova, S. (2008), “Positive and negative brand beliefs and brand defection/uptake”, European Journal of Marketing, Vol. 42 No. 5/6, pp. 553-570.

Willer, Helga and Lukas Kilcher (Eds.) (2009) The World of Organic Agriculture - Statistics and Emerging Trends 2009. FIBL-IFOAM Report. IFOAM, Bonn, Germany and FiBL, Frick; ITC, Geneva, Switzerland, available at: http://orgprints.org/18380/16/willer-kilcher-2009.pdf (accessed 30th October 2013)

Wright, M.J., Teagle, D.A.H and Feetham, P.M. (2014), “A quantitative evaluation of the public response to climate engineering”, Nature Climate Change, Vol. 4, pp. 106- 110. 
Table 1: Taxonomy of Reasons for Choosing and Rejecting Ethical Products

\begin{tabular}{|c|c|}
\hline Reasons for Choosing & I purchase ethical products, because... \\
\hline Fit with peers & 1. It helps me fit in with my peers \\
\hline Impact & 2. It helps make a difference \\
\hline Location & 3. They are easy to find \\
\hline Leadership & 4. It can make me an opinion leader \\
\hline Savings & 5. I can save money \\
\hline Quality & 6. They are of a higher quality \\
\hline Healthiness & 7. They are healthier for me \\
\hline Identity & 8. It can help me with the creation of my positive identity \\
\hline Relevance & 9. I genuinely care about the issues they deal with \\
\hline Status & 10. They may grant me a higher status \\
\hline Innovativeness & 11. They utilise innovative technology \\
\hline Information & $\begin{array}{l}\text { 12. I am very informed and am able to distinguish between ethical and non-ethical } \\
\text { products }\end{array}$ \\
\hline Reasons for Rejecting & I do not purchase ethical products, because... \\
\hline Trialability (Risk) & 13. There is a monetary risk in trialling them \\
\hline Packaging & 14. Their packaging is unattractive or unappealing \\
\hline Non-beneficial & 15. They offer no other benefit (or product features) other than being ethical \\
\hline Scepticism & 16. I am sceptical as to how ethical these products really are \\
\hline Carefree & 17. I don't really care about the consequences of not buying ethical products \\
\hline Indifference & 18. I don't give them much thought \\
\hline Availability (in-store) & 19. They are harder to find in stores \\
\hline Availability (speciality stores) & 20. You have to go to specialty stores to buy them \\
\hline Confusion & 21. I am confused as to what makes a product ethical \\
\hline Quality & 22. They are of a lower quality \\
\hline Expensive & 23. They are too expensive for the value received \\
\hline Stigma & 24. People who buy them are given a negative stigma \\
\hline Overload & 25. I am suffering from ethical overload - I am sick of hearing about it \\
\hline
\end{tabular}


Table 2: Socio-demographic Profile of Respondents

\begin{tabular}{|c|c|}
\hline Characteristic & $\%$ \\
\hline \multicolumn{2}{|l|}{ Gender } \\
\hline Male & 49.0 \\
\hline Female & 51.0 \\
\hline \multicolumn{2}{|l|}{ Age in years } \\
\hline $18-34$ & 30.0 \\
\hline $35-54$ & 44.5 \\
\hline 55 and over & 25.5 \\
\hline \multicolumn{2}{|l|}{ Highest secondary education } \\
\hline Year 12 & 66.0 \\
\hline Year 11 and below & 34.0 \\
\hline \multicolumn{2}{|l|}{ Highest tertiary education } \\
\hline Postgraduate, Grad. diploma or Bachelor & 38.5 \\
\hline Advanced diploma or certificate & 30.5 \\
\hline None of the above & 31.0 \\
\hline \multicolumn{2}{|l|}{ Political preference (voting at last federal election) } \\
\hline Liberal or National & 32.0 \\
\hline Labour & 31.0 \\
\hline Greens & 13.0 \\
\hline Other party & 10.5 \\
\hline Did not attend last election & 6.0 \\
\hline Prefer not to answer & 7.5 \\
\hline \multicolumn{2}{|l|}{ Work status } \\
\hline Unemployed or not in labour force & 37.0 \\
\hline Employed (full or part-time) & 63.0 \\
\hline \multicolumn{2}{|l|}{ Personal annual income } \\
\hline Nil Income & 2.5 \\
\hline$\$ 1-\$ 7,799$ & 8.0 \\
\hline$\$ 7,800-\$ 12,999$ & 2.0 \\
\hline$\$ 13,000-\$ 20,799$ & 8.5 \\
\hline$\$ 20,800-\$ 31,199$ & 12.0 \\
\hline$\$ 31,200-\$ 41,599$ & 11.5 \\
\hline$\$ 41,600-\$ 51,999$ & 11.0 \\
\hline$\$ 52,000-\$ 67,599$ & 9.5 \\
\hline$\$ 67,600-\$ 83,199$ & 9.0 \\
\hline$\$ 83,200-\$ 103,999$ & 6.0 \\
\hline$\$ 104,000$ or more & 8.5 \\
\hline Prefer not to answer & 11.5 \\
\hline
\end{tabular}


Table 3: Aggregate BWS scores of reasons used to make decisions about ethical products

\begin{tabular}{|c|c|c|c|c|}
\hline Rank & Overall & I purchase ethical products, because... & Mean & Stdev. \\
\hline 1 & 1 & It helps make a difference & 5.43 & 2.68 \\
\hline 2 & 3 & I genuinely care about the issues they deal with & 4.76 & 2.63 \\
\hline 3 & 4 & They are healthier for me & 4.71 & 2.60 \\
\hline 4 & 8 & I can save money & 4.09 & 2.41 \\
\hline 5 & 11 & They are of higher quality & 3.86 & 2.47 \\
\hline 6 & 13 & They utilise innovative technology & 3.81 & 2.21 \\
\hline 7 & 15 & $\begin{array}{l}\text { I am very informed and am able to distinguish between ethical and non- } \\
\text { ethical products }\end{array}$ & 3.49 & 2.32 \\
\hline 8 & 17 & They are easy to find & 3.44 & 2.18 \\
\hline 9 & 18 & It can help me with the creation of my positive identity & 3.40 & 2.41 \\
\hline 10 & 21 & It can make me an opinion leader & 2.76 & 2.00 \\
\hline 11 & 22 & It helps me fit in with my peers & 2.67 & 1.91 \\
\hline 12 & 23 & They may grant me a higher status & 2.64 & 2.09 \\
\hline Rank & Overall & I do not purchase ethical products, because... & Mean & Stdev. \\
\hline 1 & 2 & I am confused as to what makes a product ethical & 4.88 & 2.39 \\
\hline 2 & 5 & They are too expensive for the value received & 4.57 & 2.47 \\
\hline 3 & 6 & I am sceptical as to how ethical these products really are & 4.43 & 2.48 \\
\hline 4 & 7 & I don't give them much thought & 4.29 & 2.47 \\
\hline 5 & 9 & You have to go to specialty stores to buy them & 4.05 & 2.25 \\
\hline 6 & 10 & They are harder to find in stores & 3.88 & 2.19 \\
\hline 7 & 12 & They offer no other benefit (or product features) other than being ethical & 3.85 & 2.48 \\
\hline 8 & 14 & There is a monetary risk in trialling them & 3.57 & 2.26 \\
\hline 9 & 16 & I am suffering from ethical overload - I am sick of hearing about it & 3.45 & 2.30 \\
\hline 10 & 19 & I don't really care about the consequences of not buying ethical products & 3.13 & 2.32 \\
\hline 11 & 20 & They are of lower quality & 2.81 & 1.78 \\
\hline 12 & 24 & People who buy them are given a negative stigma & 2.59 & 1.95 \\
\hline 13 & 25 & Their packaging is unattractive or unappealing & 2.47 & 1.52 \\
\hline
\end{tabular}


Table 4: Mean BWS Scores by Cluster (including ANOVA result)

\begin{tabular}{lcccccc}
\hline Reasons for & Aggregate & Cluster & Cluster & Cluster & F-statistic & Sig. \\
\hline Impact & 5.43 & 7.12 & 2.82 & 6.11 & 97.5344 & 0.0000 \\
Relevance & 4.76 & 5.52 & 2.74 & 6.22 & 44.1349 & 0.0000 \\
Healthiness & 4.71 & 6.10 & 3.49 & 4.06 & 25.9082 & 0.0000 \\
Savings & 4.09 & 4.60 & 3.68 & 3.78 & 3.2752 & 0.0399 \\
Quality & 3.86 & 5.19 & 2.35 & 3.68 & 32.5617 & 0.0000 \\
Innovativeness & 3.81 & 4.66 & 2.80 & 3.77 & 15.0033 & 0.0000 \\
Information & 3.49 & 4.54 & 2.44 & 3.16 & 18.6755 & 0.0000 \\
Location & 3.44 & 4.36 & 2.25 & 3.54 & 20.7201 & 0.0000 \\
Identity & 3.40 & 4.58 & 1.93 & 3.40 & 28.6727 & 0.0000 \\
Leadership & 2.76 & 3.43 & 2.26 & 2.31 & 8.5651 & 0.0003 \\
Fit with peers & 2.67 & 3.57 & 1.96 & 2.11 & 18.7674 & 0.0000 \\
Status & 2.64 & 3.20 & 2.06 & 2.49 & 5.9154 & 0.0032 \\
\hline & & & & & & \\
\hline Reasons for & \multirow{2}{*}{ Aggregate } & $\mathbf{C l u s t e r}$ & $\mathbf{C l u s t e r}$ & $\mathbf{C l u s t e r}$ & \multirow{2}{*}{ F-statistic } & Sig. \\
Rejecting & 4.88 & 3.18 & 6.10 & 6.06 & 54.9545 & 0.0000 \\
\hline Confusion & 4.57 & 3.37 & 6.10 & 4.51 & 28.7916 & 0.0000 \\
Expensive & 4.43 & 2.64 & 6.07 & 5.17 & 61.3912 & 0.0000 \\
Scepticism & 4.29 & 2.90 & 6.18 & 4.08 & 48.2923 & 0.0000 \\
Indifference & 4.05 & 3.72 & 4.93 & 3.40 & 8.6940 & 0.0002 \\
Speciality store & 3.88 & 3.46 & 4.10 & 4.27 & 2.6559 & 0.0728 \\
In-store effort & 3.85 & 2.18 & 5.78 & 4.03 & 63.3895 & 0.0000 \\
Non-beneficial & 3.57 & 2.84 & 4.22 & 3.90 & 8.1650 & 0.0004 \\
Trialability/Risk & 3.45 & 2.32 & 4.92 & 3.38 & 30.6492 & 0.0000 \\
Overload & 3.13 & 2.15 & 5.06 & 2.16 & 53.2455 & 0.0000 \\
Carefree & 2.81 & 2.58 & 3.49 & 2.26 & 8.6236 & 0.0003 \\
Quality & 2.59 & 2.19 & 3.54 & 1.96 & 13.8016 & 0.0000 \\
Stigma & 2.47 & 2.22 & 2.68 & 2.61 & 1.9535 & 0.1445 \\
Packaging & & & & & & \\
\hline Size of cluster & & & & & & \\
\hline & & & $\mathbf{2}$ & & & \\
\hline
\end{tabular}


Table 5: Contingency Analysis (Reason-Based Clusters x Ethical Purchase Behaviours)

\begin{tabular}{|c|c|c|c|c|c|}
\hline \multirow[b]{2}{*}{ Ethical purchasing behaviour } & \multicolumn{5}{|c|}{ Test of Independence } \\
\hline & Obs & d.f. & $\begin{array}{c}\text { Chi- } \\
\text { square }\end{array}$ & Sig. & \\
\hline Hormone-free chicken & 167 & 6 & 32.1486 & 0.0000 & $* * *$ \\
\hline Co-operative fruit and vegetable & 185 & 6 & 15.5023 & 0.0167 & $* *$ \\
\hline Recycled toilet paper & 188 & 6 & 14.7151 & 0.0226 & $* *$ \\
\hline Fair-trade coffee & 151 & 6 & 13.7311 & 0.0328 & $* *$ \\
\hline Leather substitutes or fakes & 148 & 6 & 4.8881 & 0.5582 & n.s. \\
\hline Organic fruit and vegetables & 185 & 2 & 29.3483 & 0.0000 & $* * *$ \\
\hline Environmentally safe dishwashing liquid & 156 & 2 & 22.5692 & 0.0000 & $* * *$ \\
\hline Organic chocolate & 137 & 2 & 20.3541 & 0.0000 & $* * *$ \\
\hline Free-range eggs & 164 & 2 & 20.0982 & 0.0000 & $* * *$ \\
\hline Fair Trade chocolate & 137 & 2 & 15.1183 & 0.0005 & $* * *$ \\
\hline Clothing upholding labour standards & 148 & 2 & 13.1194 & 0.0014 & $* * *$ \\
\hline Organic coffee & 151 & 2 & 10.9616 & 0.0042 & $* * *$ \\
\hline Recycled printer paper & 89 & 2 & 6.1661 & 0.0458 & $* *$ \\
\hline Dolphin-safe tuna & 124 & 2 & 6.0110 & 0.0495 & $* *$ \\
\hline Natural ingredients air-freshener & 84 & 2 & 3.5117 & 0.1728 & n.s. \\
\hline Cosmetics not tested on animals & 78 & 2 & 2.8627 & 0.2390 & n.s. \\
\hline Natural textile clothing (e.g. bamboo; hemp) & 148 & 2 & 2.4288 & 0.2969 & n.s. \\
\hline
\end{tabular}


Table 6: Purchase of ethical options in long-term purchase categories by cluster

\begin{tabular}{lrcrrr}
\hline Long-term purchase (ethical option) & $\mathbf{n}$ & $\begin{array}{c}\text { Total purchasing } \\
\text { ethical option }\end{array}$ & $\begin{array}{c}\text { Negative } \\
\mathbf{( 3 3 . 5 \% )}\end{array}$ & $\begin{array}{c}\text { Mixed } \\
\mathbf{( 2 5 \% )}\end{array}$ & $\begin{array}{c}\text { Positive } \\
\mathbf{( 4 1 . 5 \% )}\end{array}$ \\
\hline Washing machine (energy efficient) & 185 & $70.8 \%$ & $30.5 \%$ & $21.4 \%$ & $48.1 \%$ \\
Motor vehicle (hybrid) & 177 & $4.5 \%$ & $0.0 \%$ & $25.0 \%$ & $75.0 \%$ \\
Shares (ethical investment) & 96 & $18.8 \%$ & $5.6 \%$ & $33.3 \%$ & $61.1 \%$ \\
Heating system (solar) & 127 & $15.0 \%$ & $47.4 \%$ & $10.5 \%$ & $42.1 \%$ \\
Airline ticket (carbon offset) & 153 & $15.7 \%$ & $12.5 \%$ & $25.0 \%$ & $62.5 \%$ \\
\hline
\end{tabular}


Table 7: Multinomial Regression Results relating cluster membership to socio-demographics

\begin{tabular}{|c|c|c|c|}
\hline & & $\begin{array}{r}\text { Cluster } 1 \\
\text { Positive orientation }\end{array}$ & $\begin{array}{r}\text { Cluster } 2 \\
\text { Negative orientation }\end{array}$ \\
\hline & & $* *$ & \\
\hline \multicolumn{2}{|l|}{ Intercept } & $0.922(0.397) \#$ & $0.312(0.439)$ \\
\hline \multirow[t]{3}{*}{ Gender } & Male & $0.209(0.229) \# \#$ & $0.733(0.252) *$ \\
\hline & & & ** \\
\hline & Female & $-0.209(0.229) \# \#$ & $-0.733(0.252) *$ \\
\hline \multirow[t]{3}{*}{ Age } & $18-34$ & $-0.260(0.322)$ & $0.015(0.356)$ \\
\hline & $35-54$ & $0.116(0.291)$ & $0.366(0.319)$ \\
\hline & 55 and over & $0.144(0.344) \#$ & $-0.381(0.390)$ \\
\hline \multirow[t]{2}{*}{ Schooling } & Completed highest level (year 12) & $0.211(0.283)$ & $0.208(0.299)$ \\
\hline & Did not complete highest level & $-0.211(0.283)$ & $-0.208(0.299)$ \\
\hline & Postgrad, graduate diploma or & & \\
\hline \multirow[t]{3}{*}{ Education } & Bachelor degree & $-0.135(0.346) \#$ & $-0.636(0.380) *$ \\
\hline & Advanced diploma or certificate & $0.299(0.306)$ & $0.263(0.335)$ \\
\hline & None of the above & $-0.164(0.350) \#$ & $0.373(0.373)$ \\
\hline \multirow[t]{2}{*}{ Work status } & Unemployed or not in labour force & $-0.234(0.271)$ & $-0.375(0.298)$ \\
\hline & Employed full-time or part-time & $0.234(0.271)$ & $0.375(0.298)$ \\
\hline \multicolumn{4}{|c|}{ - } \\
\hline \multirow[t]{4}{*}{ Orientation } & Labour & $-0.639(0.330) *$ & $-0.806(0.380) * *$ \\
\hline & Liberal & $1.070(0.433)^{* *}$ & $1.190(0.459)^{* *}$ \\
\hline & Green & $-0.555(0.421)$ & $-0.954(0.508) *$ \\
\hline & Other & $0.124(0.383)$ & $0.570(0.402)$ \\
\hline \multicolumn{2}{|l|}{ Income } & $-0.006(0.008)$ & $-0.003(0.008)$ \\
\hline \multicolumn{4}{|c|}{ Base category is cluster 3 (mixed orientation) } \\
\hline \multicolumn{4}{|c|}{ Coefficient significant at: $* 0.1, * * 0.05, * * * 0.01$ compared with cluster 3 (mixed orientation) } \\
\hline \multicolumn{4}{|c|}{ Coefficient significant at: \#0.1, \#\#0.05, \#\#\#0.01 compared with cluster 2 (negative orientation) } \\
\hline \multicolumn{4}{|c|}{ Log-likelihood (no coefficients): -181.187; Log-likelihood model: -161.42; McFadden Pseudo R-square: .105 } \\
\hline
\end{tabular}


Figure 1: Segment representation amongst those never or rarely purchasing ethically

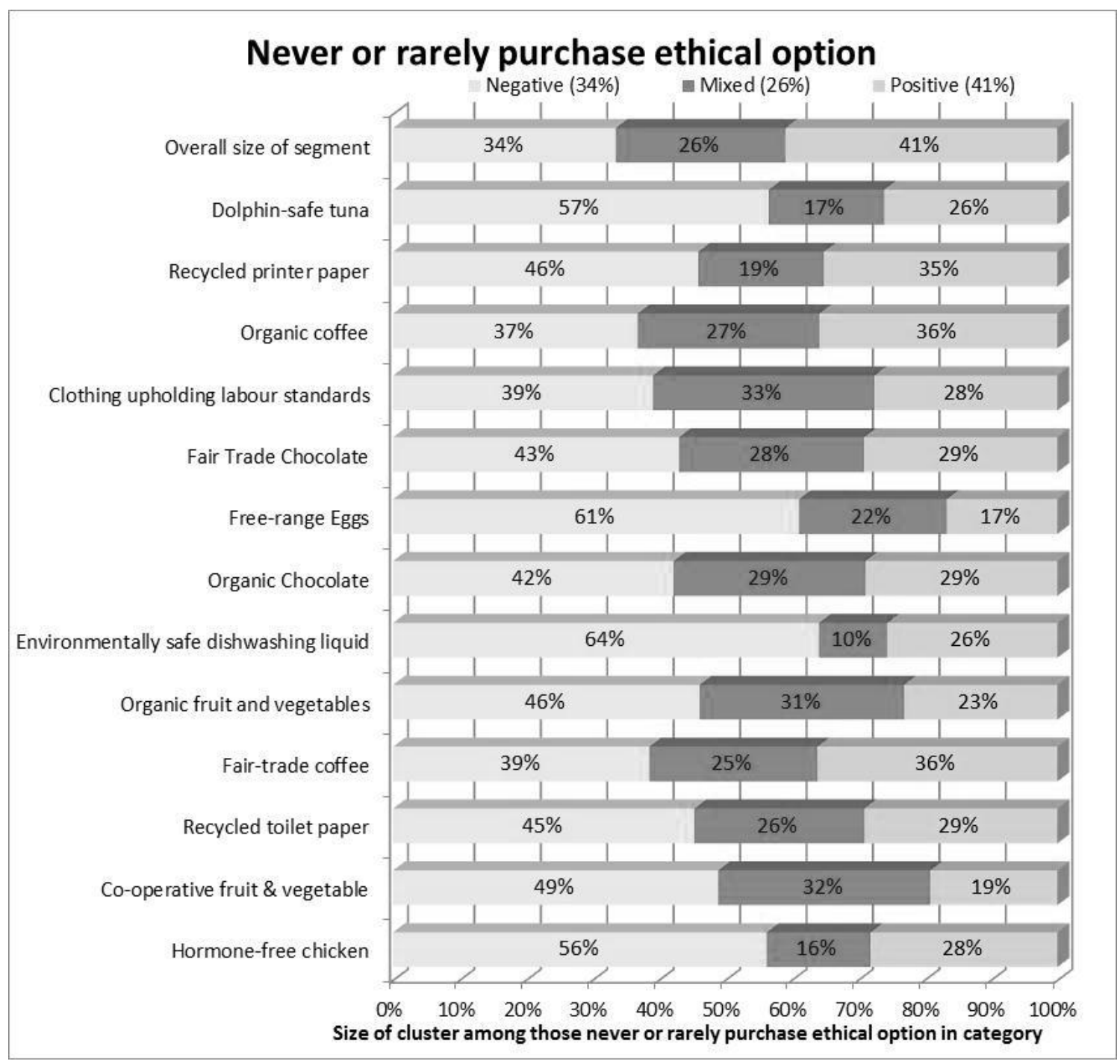


Figure 2: Segment representation amongst those occasionally or frequently purchasing ethically

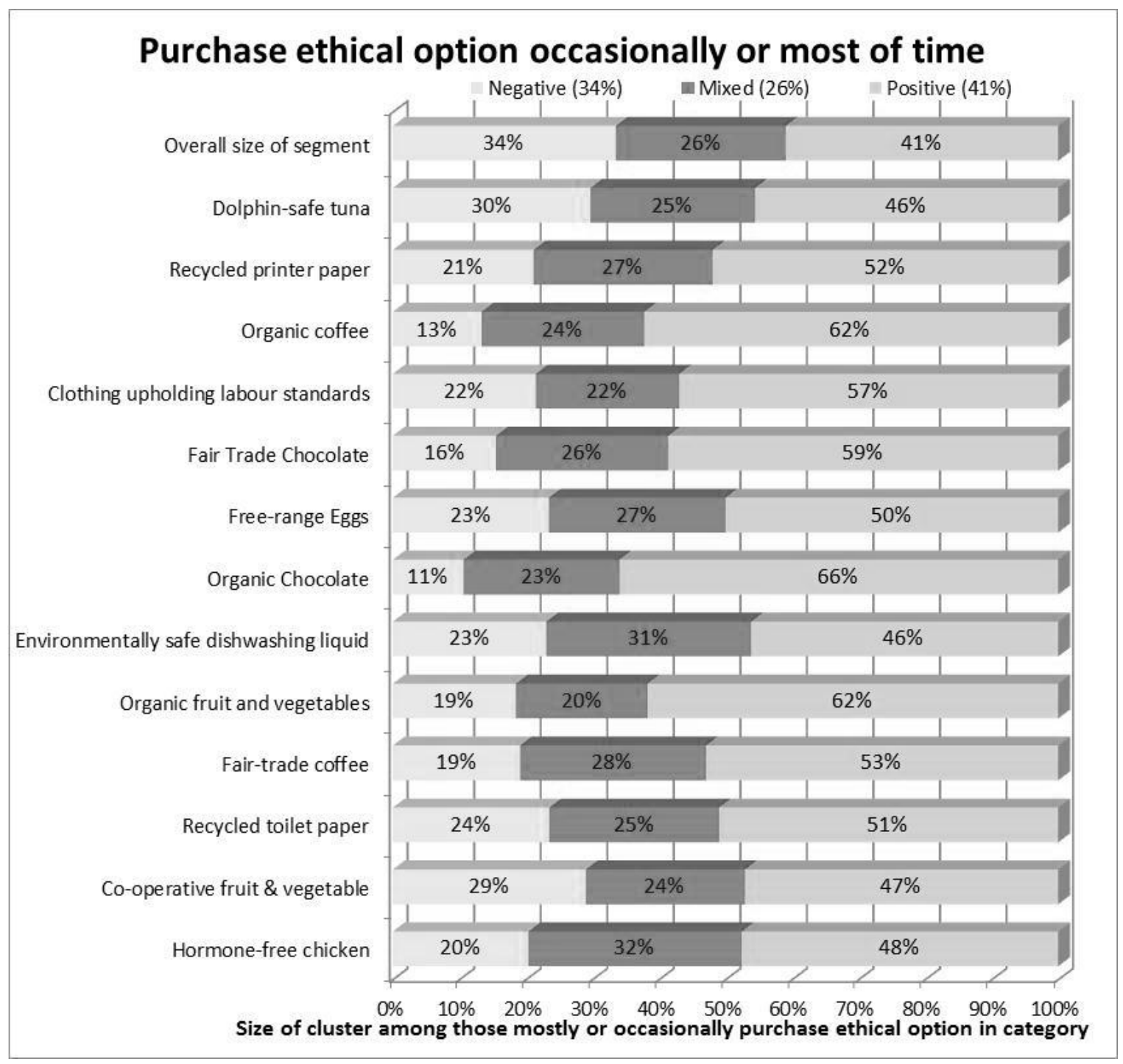

